UDC $634.25 / .26-152.73$

COBISS.SR-ID 250146828

Original research paper

Acta Agriculturae Serbica, Vol. XXII, 43 (2017); 3-9

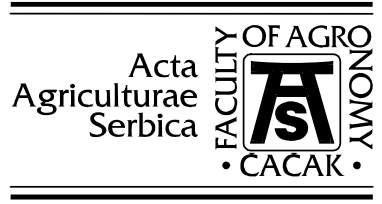

\title{
Study on the red-leaf hybrid no. 9-205 as a rootstock for peach and nectarine cultivars
}

\author{
Argir Zhivondov ${ }^{1}$, Dimitar Vasilev ${ }^{2}$, Svetoslav Malchev ${ }^{1}$, Lilyana \\ Nacheva ${ }^{1}$, Petya Gercheva ${ }^{1}$ \\ ${ }^{1}$ Fruit-Growing Institute, Plovdiv, Bulgaria \\ ${ }^{2}$ Experimental Station of Agriculture, Khan Krum, Bulgaria \\ Corresponding author: a.zhivondov@abv.bg
}

\begin{abstract}
The aim of the present study was to establish the growth characteristics of the red-leaf peach hybrid No. 9-205, grown in a nursery, targeting its submission in future for recognition as a new vegetative rootstock for peach and nectarine cultivars. The traditional seedling rootstock 'Elberta' and the vegetative one GF-677 were included in the study. Hybrid No. 9-205 was selected from a population obtained at the FruitGrowing Institute in Plovdiv by open pollination of Rutgers Red Leaf seedling rootstock for peach, used in the past. It is characterized by high drought resistance and good resistance to diseases and pests. It is easily propagated under in vitro conditions and shows weaker growth compared to GF-677 rootstock. 18 cultivar/rootstock combinations were studied, including two cultivars of each peach type: for fresh consumption, for processing and of the nectarine type. 'Laskava' cultivar for fresh consumption, the processing cultivar 'Spasena' and the cultivar 'Gergana', which is of the nectarine type, are newly established in result of the implementation of the breeding programme at the Fruit-Growing Institute - Plovdiv. They were officially recognized in the period 20092012. The percentage of survival and of grafted bud shooting is high enough and meets the requirements of the production practices in nurseries. The planting material of the vegetative rootstock No. 9-205 is uniform in plant height and stem width and it fully complies with the quality standards.
\end{abstract}

Key words: peach, nectarine, rootstocks, nursery. 


\section{Introduction}

Tree pruning and fruit harvesting account for a large share of the production costs when growing peaches and nectarines. The expenditures are significantly reduced if, when establishing new plantations, the chosen rootstocks induce tree dwarfing.

In the last 15 years a number of new rootstocks for peach and nectarine cultivars were established and studied in the frames of various breeding programs. The main criteria, followed when developing new rootstocks, are: resistance to nematodes; disease resistance; growth vigour; adapted to be grown on alkaline, heavy and wet soils. Last but not least, is the requirement for frost resistance (Birne, 2002; Reighard, 2000; Reighard et al., 2004; DeJond et al., 2007; Weibel and Reighard, 2012).

The clonal rootstock GF-677 $(P$. persica $\times$ P.amigdalus) induces vigorous growth of the trees, the fruit yields are higher and the fruit size is medium to large (Loreti and Massai, 2002). The same authors found out that the rootstock 'Barrier 1' $(P$. persica $\times P$. davidiana) adapts very well to different soil and climatic conditions, but the vegetative growth and yield from trees grafted on it are by $15 \%$ lower compared to those grafted on GF- 677 .

Over a long period of time $70 \%$ of the peach and nectarine plantations in Italy have been grown on GF-677 rootstock, and only $20 \%$ of the plantations on seedling rootstocks (Fideghelli, 2003).

In Bulgaria, seedlings from late peach cultivars are still used as rootstocks in the production of peach and nectarine planting material. Due to the higher prices of the planting material produced on GF-677 rootstock, it enters the production process quite slowly (Gyurcheva-Karadzhova, 1985; Andonova, 2004).

In this regard, the aim of the present study was to identify the growth characteristics of the red-leaf peach hybrid No. 9-205 grown in the nursery as a new vegetative rootstock for peaches and nectarines and to compare it with the traditional seedling rootstock and the vegetative rootstock GF-677.

\section{Material and methods}

Studies were carried out in 2011-2013 on the fruit-tree nursery site at the Agricultural Experimental Station in Khan Krum, Shumen region. A total of 18 cultivar/rootstock combinations were investigated. The trial was conducted in three replications with 15 trees of each combination per replication. A total of 6 cultivars were studied: the nectarine cultivars 'Gergana' and 'Morsiani 51', the peach cultivars of the group for fresh consumption 'Royal Glory' and 'Laskava' and the peach cultivars for processing 'Baby Gold 9' and 'Spasena'. The cultivars were grafted on a seedling rootstock, obtained from seeds of cv. 'Elberta', and on the clonal rootstocks GF-677 and the red-leaf hybrid No. 9-205. Hybrid No. 9-205 was selected at Fruit-Growing Institute in Plovdiv from a 
population obtained by open pollination of the seedling peach rootstock 'Rutgers Red Leaf', used in the past. It is characterized by a high drought resistance, as well as disease and pest resistance. Under in vitro conditions it shows a very good reproductive capacity and it has a weaker growth rate than GF-677 rootstock (Nacheva et al., 2010).

The cultivars 'Gergana', 'Laskava' and 'Spasena' are newly established in result of the implementation of the breeding programme at the Fruit-Growing Institute - Plovdiv and they were officially registered in the period 2009-2012 (Zhivondov, 2012; Lazarov and Zhivondov, 2014).

T-shaped budding on a dormant bud was performed in the middle of August and the following characteristics were reported:

- Bud survival percentage - 25 days after grafting;

- $\quad$ Bud sprouting percentage in the next spring - at the end of April;

- $\quad$ Tree height at the end of the vegetation season - 20-30 October;

- Stem thickness of the trees at $15 \mathrm{~cm}$ above the place of grafting at the end of the vegetation season - 20-30 October.

Statistical data processing was performed by Duncan's criteria (Lidanski, 1988).

\section{Results and discussion}

The results of the average data for the three-year period of the study are presented in Table 1. The best bud survival in the autumn reporting period (25 days after grafting) was established in GF-677 rootstock. Exceptions were established in 'Royal Glory' cultivar, which had the highest bud survival percentage on the seedling rootstock $(97.8 \%)$, as well as in 'Spasena' cultivar grafted on hybrid No. 9-205 (97.4\%).

The results of the spring bud sprouting did not show a clear tendency in favour of any of the studied rootstocks. The percentages varied from $79.35 \%$ in the cultivar/rootstock combination 'Baby Gold' on a seedling rootstock to $94.5 \%$ in 'Gergana' on GF-677. As a whole, the results of the bud survival percentage in the autumn reporting period were by $3-9 \%$ better compared to the bud sprouting percentage in spring, which is accepted as normal in fruit-growing practice.

The results of the seedling rootstock in the autumn reporting period varied from $88.7 \%$ in 'Baby Gold' cultivar to $97.8 \%$ in 'Royal Glory'. Statistically significant higher percentage of bud sprouting in spring was established in the cultivars 'Laskava' - 91.8\%, 'Royal Glory' - 91.3\% and 'Morsiani 51' $-91.1 \%$. Statistically significant lower values were reported in the cultivars of processing type - 'Baby Gold 9' - 79.3\% and 'Spasena' $-81.3 \%$. 
Table 1. Bud survival percentage, in average for the period 2011-2013

\begin{tabular}{|c|c|c|c|c|c|c|}
\hline \multirow{3}{*}{ Cultivars } & \multicolumn{6}{|c|}{ Rootstocks } \\
\hline & \multicolumn{2}{|c|}{ Seedling } & \multicolumn{2}{|c|}{ INRA GF-677 } & \multicolumn{2}{|c|}{ Hybrid $N^{\circ} 205$} \\
\hline & $\begin{array}{l}\text { Autumn } \\
\text { reporting }\end{array}$ & $\begin{array}{l}\text { Spring } \\
\text { reporting }\end{array}$ & $\begin{array}{l}\text { Autumn } \\
\text { reporting }\end{array}$ & $\begin{array}{l}\text { Spring } \\
\text { reporting }\end{array}$ & $\begin{array}{l}\text { Autumn } \\
\text { reporting }\end{array}$ & $\begin{array}{l}\text { Spring } \\
\text { reporting }\end{array}$ \\
\hline $\begin{array}{l}\text { Гергана } \\
\text { Gergana }\end{array}$ & $97.7 \mathrm{a}$ & $85.0 \mathrm{~b}$ & $99.4 \mathrm{a}$ & $94.5 \mathrm{a}$ & $90.7 \mathrm{~b}$ & $88.5 \mathrm{ab}$ \\
\hline $\begin{array}{l}\text { Морсиани } 51 \\
\text { Morsiani } 51\end{array}$ & $95.6 \mathrm{a}$ & $91.1 \mathrm{a}$ & $97.2 \mathrm{ab}$ & $82.6 \mathrm{~d}$ & $91.6 \mathrm{~b}$ & $86.7 \mathrm{~b}$ \\
\hline $\begin{array}{l}\text { Ласкава } \\
\text { Laskava }\end{array}$ & $94.4 \mathrm{a}$ & $91.8 \mathrm{a}$ & $98.8 \mathrm{ab}$ & $86.4 \mathrm{c}$ & $93.2 \mathrm{~b}$ & $81.8 \mathrm{c}$ \\
\hline $\begin{array}{l}\text { Роял Глори } \\
\text { Royal Glory }\end{array}$ & $97.8 \mathrm{a}$ & $91.3 \mathrm{a}$ & $95.3 \mathrm{~b}$ & $91.5 \mathrm{~b}$ & $90.5 \mathrm{~b}$ & $82.4 \mathrm{c}$ \\
\hline $\begin{array}{l}\text { Бейбиголд } 9 \\
\text { Baby Gold } 9\end{array}$ & $88.7 \mathrm{~b}$ & $79.3 \mathrm{c}$ & $94,7 \mathrm{~b}$ & $83.8 \mathrm{~cd}$ & $86.2 \mathrm{c}$ & $81.1 \mathrm{c}$ \\
\hline $\begin{array}{l}\text { Спасена } \\
\text { Spasena }\end{array}$ & $95,2 \mathrm{a}$ & $81.3 \mathrm{c}$ & $96.6 \mathrm{ab}$ & $85.4 \mathrm{c}$ & $97.4 \mathrm{a}$ & $91.9 \mathrm{a}$ \\
\hline LSD $5 \%$ & 4.1 & 3.1 & 3.7 & 2.6 & 3.8 & 2.5 \\
\hline
\end{tabular}

Comparatively higher bud survival percentage in the autumn reporting period was established on the clonal rootstock GF-677. The values varied from $94.7 \%$ in 'Baby Gold 9' cultivar to $99.4 \%$ in 'Gergana'. The percentage of bud sprouting in spring on the same rootstock was from $82.6 \%$ in 'Morsiani 51 ' to $94.5 \%$ in 'Gergana'. Cultivar 'Gergana' of the nectarine type and 'Royal Glory' cultivar for fresh consumption showed the highest percentage of bud sprouting in the next spring. Statistically significant lower values of the bud sprouting in the next spring were reported in the cultivars 'Morsiani 51' and 'Baby Gold 9'.

Data about the survival percentage in the autumn of the buds grafted on the new vegetative rootstock No. 9-205 varied from 86,2\% in 'Baby Gold 9' cultivar to $97.4 \%$ in 'Spasena' cultivar. Comparatively good results were reported in the cultivars 'Laskava' and 'Morsiani 51' - 93.2\% and 91.6\%, respectively. Values of the bud sprouting percentage in the next spring varied from $81.1 \%$ in 'Baby Gold 9' cultivar to $91.9 \%$ in 'Spasena'. Comparatively good results were also obtained in 'Gergana' and 'Morsiani 51' cultivars - 88.5\% and $86.7 \%$, respectively. In the other cultivars grafted on rootstock No. 9-205 the bud 
sprouting percentages in the next spring were over $80 \%$, a result that fully satisfies the requirements of agricultural practice in nurseries.

Table 2. Size of the obtained trees in the nursery in the second year (in average for the period 2011-2013)

\begin{tabular}{|c|c|c|c|c|c|c|}
\hline \multirow{3}{*}{ Cultivars } & \multicolumn{6}{|c|}{ Rootstocks } \\
\hline & \multicolumn{2}{|c|}{ Seedling } & \multicolumn{2}{|c|}{ INRA GF-677 } & \multicolumn{2}{|c|}{ Hybrid $N^{\circ} 205$} \\
\hline & $\begin{array}{l}\text { Height } \\
/ \mathrm{cm} /\end{array}$ & $\begin{array}{c}\text { Stem } \\
\text { thickne } \\
\text { ss } / \mathrm{mm} /\end{array}$ & $\begin{array}{l}\text { Height } \\
/ \mathrm{cm} /\end{array}$ & $\begin{array}{c}\text { Stem } \\
\text { thickness } \\
/ \mathrm{mm} /\end{array}$ & $\begin{array}{l}\text { Height } \\
/ \mathrm{cm} /\end{array}$ & $\begin{array}{c}\text { Stem } \\
\text { thickness } \\
/ \mathrm{mm} /\end{array}$ \\
\hline $\begin{array}{l}\text { Гергана } \\
\text { Gergana }\end{array}$ & $153.7 \mathrm{~b}$ & $17.3 \mathrm{ab}$ & $164.4 \mathrm{c}$ & $17.5 \mathrm{bc}$ & $121.1 \mathrm{a}$ & $11.2 \mathrm{bc}$ \\
\hline $\begin{array}{l}\text { Морсиани } 51 \\
\text { Morsiani } 51\end{array}$ & $125.3 \mathrm{~d}$ & $15.6 \mathrm{bc}$ & $133.7 \mathrm{e}$ & $15.7 \mathrm{c}$ & $112.6 \mathrm{~b}$ & $11.4 \mathrm{~b}$ \\
\hline $\begin{array}{l}\text { Ласкава } \\
\text { Laskava }\end{array}$ & $150.6 \mathrm{bc}$ & $18.0 \mathrm{a}$ & $160.4 \mathrm{~d}$ & $18.9 \mathrm{~b}$ & $121.6 \mathrm{a}$ & $11.5 \mathrm{ab}$ \\
\hline $\begin{array}{l}\text { Роял Глори } \\
\text { Royal Glory }\end{array}$ & $154.3 \mathrm{~b}$ & $16.1 \mathrm{~b}$ & $163.8 \mathrm{c}$ & $18.7 \mathrm{~b}$ & $116.6 \mathrm{ab}$ & $12.9 \mathrm{a}$ \\
\hline $\begin{array}{l}\text { Бейбиголд } 9 \\
\text { Baby Gold } 9\end{array}$ & $142.9 \mathrm{c}$ & $14.0 \mathrm{c}$ & $175.1 \mathrm{~b}$ & $185.1 \mathrm{~b}$ & $118.6 \mathrm{ab}$ & $9.8 \mathrm{c}$ \\
\hline $\begin{array}{l}\text { Спасена } \\
\text { Spasena }\end{array}$ & $179.8 \mathrm{a}$ & $16.9 \mathrm{ab}$ & $188.8 \mathrm{a}$ & $21.7 \mathrm{a}$ & $120.6 \mathrm{a}$ & $10.0 \mathrm{bc}$ \\
\hline LSD $5 \%$ & 10.4 & 1.9 & 3.2 & 1,8 & 7.0 & 1.5 \\
\hline
\end{tabular}

At the end of vegetation the largest height and stem thickness was established in the trees of all the cultivars, grafted on GF-677 rootstock (Table 2). The results confirmed the known fact for the more vigorous growth induced by the clonal rootstock GF-677 in comparison with the seedling one. Smaller height and thickness was reported in the trees of all the cultivars grafted on the newly established and investigated in the present study vegetative rootstock No. 9-205. The difference between the trees grafted on GF-677 and on No. 9-205 rootstocks was about $40-60 \mathrm{~cm}$ in height and about $5-10 \mathrm{~mm}$ in stem thickness. It can certainly be stated that the rootstock No. 9-205 induces significantly weaker growth in the nursery. Further studies would provide results for the behaviour of the new rootstock in fruit-bearing plantations.

Results obtained in the nursery show that the height of the trees on the seedling rootstock varied from $125.3 \mathrm{~cm}$ in 'Morsiani 51' cultivar to $179.8 \mathrm{~cm}$ in 
'Spasena'. The trees of 'Royal Glory' and 'Gergana' were comparatively higher. The largest stem thickness was reported in the trees of 'Laskava' cultivar (18.0 $\mathrm{mm}$ ) and the smallest one - in the trees of 'Baby Gold 9' (14 mm).

Height of the trees on GF-677 rootstock varied from $133.7 \mathrm{~cm}$ in 'Morsiani 51 ' to $188.8 \mathrm{~cm}$ in 'Spasena'. Stem height of the obtained trees was from 15.7 $\mathrm{mm}$ in 'Morsiani 51' to $21.7 \mathrm{~mm}$ in 'Spasena' cultivar.

Trees of the cultivar/rootstock combinations with the participation of the red leaf hybrid No. 9-205 were most uniform in height and stem thickness. Values of tree height varied from $112.6 \mathrm{~cm}$ in 'Morsiani 51' cultivar to $121.6 \mathrm{~cm}$ in 'Laskava'. Stem thickness of the obtained trees was from $9.8 \mathrm{~mm}$ in 'Baby Gold 9' to $12.9 \mathrm{~mm}$ in 'Royal Glory'.

\section{Conclusions}

Bud survival percentage and bud sprouting percentage in all the variants is high enough and it fully meets the requirements of the production practices in nurseries.

The red leaf hybrid No. 9-205, studied as a new clonal rootstock, is suitable for the peach cultivars of the nectarine type, peach cultivars for fresh consumption and for processing. It induces a weaker growth rate of the grafted cultivars from the three groups, compared to the clonal rootstock GF-677 and the seedling rootstock. The obtained planting material is uniform in height and stem thickness and it meets the quality standards.

\section{References}

Andonova M. (2004): Peach, 'Enyovche' Publishing House, 78.

Gyurcheva-Karadzhova Y. (1985): Study of some species of Prunus L. genera as rootstocks for peach, $\mathrm{PhD}$ Thesis, 25.

Lidanski T. (1988): Statistical methods in biology and in agriculture, Zemizdat, 374.

Byrne D. (2000): Peach breeding Trends: A World Wide Perspective, Acta Horticulturae (ISHS), 592: 49-59.

Dejong T., Johnson R., Doyle J., Ramming D. (2005): Research yields size - controlling rootstocks for Peach Production, California Agriculture, 59, 2: 8083.

Fideghelli C. (2003): The peach industry in Italy: State-of-art research and development, First Mediterranean Peach Symposium, September $10^{\text {th }}$, Vols 1-2: 2226.

Lazarov I., Zhivondov A. (2014): The potential of fruit breeding science in Bulgaria for establishing new cultivars - 1959-2014. Agricultural Science, 47 (2-3): 3-22.

Loreti F., Masai R. (2002): MIPAF Targeted Project for evaluation of Peach rootstocks in Italy: Results of six years of observations. Acta Horticulturae (ISHS), 592: 58-65. 
Nacheva L., Gercheva P., Zhivondov A. (2010): Micropropagation of red leaf peach hybrid (Prunus persica L.) Acta Horticulturae (ISHS), 885: 223-229.

Reighard G. (2000): Peach rootstocks for the United States: Are foreign rootstocks the answer? Hort Technology, 10 (4): 714-718.

Reighard G., Andersen R., Anderson J., Autio W., Beckman T., Baker T., Belding R., Brown G., Byers P., Cowgill W., Deyton D., Durner E., Erb A., Feree D., Gaus A., Godin R., Hayden R., Hirst P., Kadir P., Kaps M., Larsen H., Lindstrom T., Miles N., Morrison F., Myers S., Oulette D., Rom C., Shane W., Taylor B., Taylor K., Walsh C., Warmund M. (2004): Growth and yield of Redhaven peach on 19 rootstocks at 20 North American locations. Journal American Pomol. Soc., 58 (4): 174 - 202.

Weibel A., Reighard G. (2012): Dwarfing Peach Rootstocks generate scion water stress. Acta Horticulturae (ISHS), 962: 633-639.

Zhivondov A. (2012): Plumcots - Remote hybridization of fruit species in Bulgaria. Monograph. 'Reklama pony' Publishing House, Sofia. 